\title{
Developing Speaking Materials Through Problem Based Learning For D-3 Mechanical Engineering Students At State University Of Medan
}

\author{
Sutresno, I Wayan Dirgeyasa Tangkas \\ English Applied Linguistics Study Program, \\ Postgraduate School, Universitas Negeri Medan, \\ Medan, Indonesia \\ sutresnoutomo479@yahoo.co.id
}

\author{
Sri Minda Murni \\ Linguistic Study Program \\ Universitas Sumatera Utara \\ Medan, Indonesia
}

\begin{abstract}
The Purpose of this study are; 1) to examine the existing speaking materials; 2) to find out the speaking materials needed by the students; 3) to develop the speaking materials based on problem based learning. Research method of this study was applied Educational Research and Development model by Gall, Gall and Borg, 2003, but in implementing the model is simplified and adapted to Dirgayasa (2011) become four steps: 1) Evaluation and need analysis, 2) designing new material, 3) validating material, 4) revision and final production. The Instrument of collecting the data was collected by questionnaire, documentation sheet and interview. The source of the data was the students of 1st semester academic year 2016/2017, Engineering lecturer, stakeholder, alumnus and also syllabus and the existing speaking material used today. The result of this study relevance the existing speaking material is $17.36 \% .98 .24 \%$ students agree book are developed. Speaking material are needed by students are 1) Wheel Bearings; 2) Can not starter; 3) Overheating Engine; 4) How Cars Work;5) Car Maintenance;6) Hydro Power Plant and 7) Boiler. The final result of this research is developing material through problem based learning learning become some activities; Direct students to observe the object. Ask problem of object. Collect data to answer problem. Formulate the problem, communication.
\end{abstract}

Keywords - Speaking material; problem based learning; engineering

\section{INTRODUCTION}

This research was called development research. According Borg and Gall (1983:772) Development research is Educational Research and development (R \& D) is a process used to develop and validate educational products. The steps of this process are usually referred to as the R \& D cycle, which consists of studying research findings pertinent to the product to be developed, developing the products based on these findings, field testing it in the setting where it will be used eventually, and revising it to correct the deficiencies found in the filed-testing stage. In more rigorous programs of $\mathrm{R} \& \mathrm{D}$, this cycle is repeated until the field-test data indicate that the product meets its behaviorally defined objectives.
In this of study Speaking become chosen subject matter by researcher because speaking very important to their career. According to Tarigan (1990:3-4) defines that speaking is a language skill that is developed in child life, which is produced by listening skill, and at that period speaking skill is learned. And then according Speaking is an interactive process of constructing meaning that involves producing and receiving and processing information (Brown, 1994; Burns \& Joyce, 1997).

In this of the research mechanical engineering study program D-3 become choosen by researcher. Mechanical engineering is the engineering science of the application of physical principles to the analysis, design, manufacturing and maintenance of a mechanical system. This science requires deep understanding of the main concepts of the branches of mechanics, kinematics, material engineering, thermodynamics and energy. Experts or experts from mechanical engineering are usually referred to as engineers, who make use of this understanding of engineering in designing and analyzing the manufacture of vehicles, aircraft, industrial plants, industrial equipment and machinery and so on

In this reseacrh book developed was English speaking material for D-3 mechanical engineering textbook. There is problem in this study that is there is no English speaking material specially. And the gap in this study program that is students can not speaking about mechanical engineering. This research is said to be interesting and motivation by students because this research developing english speaking materials through problem based learning. According Necati Hirca in Inel and Balim (2010) that PBL is a learning method that uses problems as a basis for students to improve their problem-solving skills and to obtain knowledge.

A problem based learning may suit on the development of speaking materials english for mechanical mechanical enginering. it is assumed that it enable the students not only to the mastery of the subject itself but also involve the students actively either by group or individual to teaching and learning process. in additin tbl also is assumed to be able 
to motivate and encourage the students to learn more actively and participatyvely. also by using PBL students can do peer review during the process of teaching and learning.

The strengts of the new speaking material was (1) systematically (2) mechanary vocabulary (3) there are pictures related mechanary (4) students centre approach.

\section{Methodology}

\section{A. Research method}

Research method of this study was applied Educational Research and Development (E-RD) model by Gall, Gall and Borg (2003) which consists of a set of steps to develop new educational product. The chosen of this research process to develop a quality product design to meet the need of the specific materials that can be used at D-3 mechanical engineering. It is in line with the primary goal of R \& D is to discover knew knowledge, then take and incorporate it into a product that can be used in the college.

\section{B. Data and data source}

The data of this research were Texbook, syllabus, curriculum, questionnaire result, interviews result, The data source of this research such were: a). Students of D-3 mechanical engineering study program in first semester in academic years $2017 / 2018$. They are only a local with a total of 24 students 2). Mechanical Engineering lecturer 3). Alumni 4). Stake Holders

\section{RESULT AND DISCUSSIONS}

This part deals with the description of the answer of problems. There are three research problems proposed in the thesis. (1) How are the existing English speaking materials used by the students of D-3 mechanical engineering study program at UNIMED in the first semester of the academic year of 2017/2018? (2) What English speaking materials are needed by the students of D-3mechanical engineering study program at UNIMED in the first semester of the academic year of 2017/2018? (3) How are the English speaking materials the students of D-3 mechanical engineering study program at UNIMED in the first semester of the academic year of 2017/2018 developed basedon the problem based learning?

The answer of the questions number 1 . How are the existing English speaking materials? as for the conclusion of the relevant existing speaking material at the moment is 17 . $36 \%$. For more details can be seen below. As for a detailed explanation of the results of the evaluation of the above teaching materials is as follows.

\section{A. Objectives}

In this objective there are three items, the first item is whether the purpose material appropriate for students get
0.41 score with 10.41 percentage categorynot relevant. The second whether the material compatible for the situation get 0.87 with $21.8 \%$ category lessrelevant. The last materials provide speaking skill get 0.79 with $19.7 \%$ category less relevant.

\section{B. Design and Lay out}

In this Design and Lay out there are five questions. The fisrt How is the arrangement of the existing speaking material? (structure, function, topic and skill) get 0.66 score with $16.6 \%$ category less relevant. The second, How is the structure of the existing speaking material? Get 0.87 score with 21.8 category less relevant. The thirth, How is the correlation of each topic in the existing speaking materials, whether it supports the mastery of the next topic? get 0.79 score with $19.7 \%$ category less relevant. The fourth, Whether the existing speaking material provided picture/illustration which has correlation? get 0.66 score with $16.6 \%$ category less relevant. The fifth, Whether the topics/the material is clear enough? get 0.87 score with 21.8 $\%$ category less relevant

\section{Linguistic Features}

In this linguistic features there are four items. The first about material covered the grammar and appropriate level and need get 0.54 score with $13.54 \%$ category not relevant. The second about material provided vocabularies list get 0.79 score with $19.7 \%$ category less relevant. The third about material meaningful and easy get 0.79 score with $19.7 \%$ category less relevant. The last about material provided language use get 0.91 score with $22.91 \%$ category less relevant.

\section{Topic}

In this linguistic features there are four items. The first about speaking material attractive get 0.75 score with $18.75 \%$ category less relevant. The second about speaking material appropriate level get 0.66 score with $16.6 \%$ category less relevant. The third about speaking material activates knowledge get 0.66 score with $16.6 \%$ category less relevant. The last about speaking material appropriate expertise program get 0.70 score with $17.70 \%$ category less relevant.

\section{E. Learning Method}

In this learning method there are six items. The first about material motivates learning English get 0.79 score with $19.7 \%$ category less relevant. The second about material drive think critically get 0.91 score with $22.91 \%$ category less relevant. The third about material allow do self study get 0.79 score with $19.7 \%$ category less relevant. The fourth about method applicable for learning process get 0.62 score with $15.62 \%$ category less relevant. The five about material can aplly peer review get 0.5 score with $12.5 \%$ category not relevant. The last about method based applicable in learning process get 0.79 score with $18.73 \%$ category less relevant. 


\section{F. Difficulties in Speaking}

In this difficulties in Speaking the are three. The fisrt about mastery of vocabulary get 0.75 score with $18.75 \%$ category less relevant. The second about understanding in speaking get 1.04 score with $26,04 \%$ category notrelevant.The last about pronunciation get 0.62 score with $15.62 \%$ category less relevant.

The answer of the questions number 2. What English speaking material are needed? The mechanical engineering lecturer suggested there was a topic about can not starter and overheating engine. Students suggested there was car maintenance and how cars work. The alumni suggested there is one topics wheel bearing. The first stake holder were PT PLN Medan suggested there was a topic Hydro Power Plant". So that employees can work better. While the second were PT Losum Medan suggested there was a topic Boiler"Ketel Uap. So that employees understand how the boiler can produce good steam so it can be used for the process of maintaining the temperature in the petroleum distillation column and evaporator process in the evaporator.

The answer of the questions number 3. How are the English speaking materials developed based on the problem based learning? The English speaking materials developed according by Barret (2005) describes the steps of implementing PBL as follows:

1) Students are given problems by the teacher (or issues expressed from the student's experience)

2) Students conduct small group discussions and do the following.

Clarify the case of the given problem Define the problem Make a swap based on the knowledge they have Sets the things needed to solve the problem Establish things to do to resolve the issue

3) Students conduct independent studies in relation to issues to be solved.

They can do this by searching sources in libraries, databases, the internet, personal resources or observing

4) Students return to the original PBM group to exchange information, peer learning, and work in solving problems.

5) Students present the solutions they find

\section{CONCLUSION}

The analysis existing speaking matessssssrials was done. The conclusion is $17.36 \%$ relevance existing speaking maerials used by the first semester. and analysis of the need analysis speaking materials was done. The conclusion is 98 . $24 \%$ students very needed book are developed.
From interviews of students, stake-holder, alumni and engineering lecturer conclude that the important need for students that can be implemented their knowledge in the factory must be correlated with the topics of Wheel Bearings, Starter, Overheating Engine, How Cars Work, Car Maintenance, Hydro Power Plant and Boiler

Problem based learning model become the interesting and creative for English lecture to teach ESP especially in speaking because the process of learning will make the situation relax and enjoy and it makes the speaking process become easier. There are five stage of problem based learning namely; Direct students to observe the object, Proffer and ask problem of object, Collect data to answer problem, Formulate answer of problem Communicate answers the result of the problem.

\section{REFERENCES}

1. Anderson, J. R. (1993). Problem Solving and Learning. American Psychologist

2. Antony, E. Does problem-based learning improve problem solving skills? - a study among business undergraduates at malaysian premier technical university. International Education Studies; Vol. 9, No. 5; 2016 ISSN 1913-9020 E-ISSN 1913-9039

3. Alan G. Fincham \& Charles F. Shuler (2001). The Changing Face of Dental Education:The Impact of PBL. Journal of Dental Education Volume 65, No. $\quad 5 . \quad$ From http://citeseerx.ist.psu.edu/viewdoc/download?doi=10.1.1.490.9509\&r ep=rep1\&type $=$ pdf

4. Arikunto, S.2009. Prosedur Penelitian Suatu Pendekatan Praktik. Edisi 6. Jakarta.Rineka Cipta.

5. Ary,et al. 2010. Introduction to research in education. (8th ed). Belmint, wadsworth cengage learning.

6. Barrett, T., Mac Labhrainn, I., Fallon, H. (Eds) (2005). Handbook of Enquiry and Problem-based Learning: Irish Case Studies and International Perspectives. Galway: AISHE and CELT, NUI Galway

7. Barrows, H. S., \& Tamblyn, R. M. (1990. Problem Based Learning An Approach To Medical Education, New York; Springer

8. Bandono. Pengembangan bahan ajar./http/www/file/J/pengembangan bahan ajar - bandono/htm/.retrived september 12,2013.

9. Bogdan, R.C. and Biklen, S.K. 1992. Qualitative Research For Education: An Introduction to Theory and Method. Boston: Allyn and Bacon, Inc.

10. Bridges, E. M., \& Hallinger,p.1995.Problem Based Learning In Leadership Development. Portland; University Of Oregon. ERIC Clearing House on Educational Management.

11. Britis Council, 1978. ELT Document English for Specific Purpose. London

12. Broughton, G \& Brumpit C. 2003.Teaching English as a Foreign Language. University of London Institute of Education. 